\title{
Polish Theriological Bibliography, 1987
}

\author{
POLSKA BIBLIOGRAFIA TERIOLOGICZNA, 1987 \\ ПОЛЬСКАЯ ТЕРИОЛ̆ОГИЧЕСКАЯ БИБЛИОГРАФИЯ, 1987
}

\author{
Michalina PUCÉK
}

I. List of periodical titles and their abbreviations . . . . . . . 595

II. Titles of papers not included in previous issue for 1986 . . . . 596

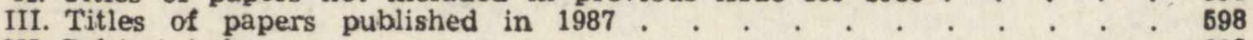

IV. Subject index .
0 . General literature
1. Evolution and Genetics
2. Morphology
3. Physiology
4. Reproduction, Sex, Hybridisation
5. Development
6. Ecology, Biology and Conservancy
7. Distribution, Fauna and Systematics, Palaentology
8. Parasites, Epidemiology and Pathology

\section{LIST OF PERIOLODICAL TITLES AND THEIR ABBREVIATIONS}

Acta anat.

Acta biol. siles. US1.

\section{Acta palaeont. pol.}

Acta parasit. pol.

Acta physiol. pol.

Acta theriol.

Acta zool. cracov.

Afr. Small Mammal Newslet.

Annls Univ. M. Curie-Skłodowska, C

Annls Univ. M. Curie-Skłodowska, D

Annls Univ. M. Curie-Skłodowska, DD

Anat. Ane.

Bad. fizjogr. Pol. zach., C

Biochem. Syst. \& Ecol.
- Acta Anatomica, Basel-New York

- Acta Biologica Silesiana, Prace Naukowe Uniwersytetu Śląskiego

- Acta Palaeontologica Polonica, War-

- Acta Palaentologica Polonica, Warszawa

- Acta Parasitologica Polonica, Warszawa

- Acta Physiologica Polonica, Warszawa

- Acta Theriologica, Białorwieża-Warszawa

- Acta Zoologica Cracoviensia, Kraków

- African Small Mammal Newsletter, Antwerpen

- Annales Universitatis Mariae Curie-Sklodowska, Sectio C, Biologia, Lublin

- Annales Universitatis Mariae Curie-Sklodowska, Sectio D, Medicina, Lublin

- Annales Universitatis Mariae Curie-Skłodowska, Sectio DD, Medicina Veterinaria, Lublin

- Anatomischer Anzeiger, Jena

- Badania Fizjologicme nad Polską Zachodnią, Seria C - Zologia, Poznań

- Biochemical Systematics and Ecology 


\section{Biul. IOR}

Bull. Pol. Acad. Sci., Biol. Sci.

\section{Cell Tissue Res.}

Chrońmy Przyr. ojez.

Comp. Biochem. Physiol. A

Ekol. pol.

Folia biol.

Fragm. faun.

Gen. pol.

J. Bombay nat. Hist. Soc.

J. Hirnforsch.

J. Wildl. Manage.

\section{KAW}

Kron. Wielkp.

Mat. Archeol. Nowej Huty

Med. wet.

Oecologia

Parki nar. Rez. Przyr.

Pol. Archwm. wet.

Pol. Pismo entomol.

Pr. Mat. Archeol. Etnograf. Łódź,

Ser. Archeol.

Prz. zool.

Roczn. nauk. zootechn.

Scientifur

Spr. archeol.

Symp. zool. Soc. Lond.

Wiad. ekol.

Wiad. parazyt.

Zool. Abh. Mus. Tierk. Dresden

Zool. Garten
- Biuletyn Instytutu Ochrony Roślin, Poznań

- Bulletin of the Polish Academy of Sciences, Biological Sciences, Warsaw

- Cell and Tissue Research, Springer Verlag Berlin, Heidelberg New York

- Chrońmy Przyrodę Ojczystą, Kraków

- Compactive Biochemistry and Physiology, A Physiology, Oxford

- Ekologia Polska, Warszawa

- Folia Biologica, Kraków

- Fragmenta Faunistica, Warszawa

- Genetica Polonica, Poznań

- Journal of the Bombay Natural History Society, Bombay

- Journal für Hirnforschung, Berlin

- Journal of Wildlife Management, Lawrence

- Krajowa Agencja Wydawnicza, Wroclaw

- Kronika Wielkopolska, Poznań

- Materialy Archeologiczne Nowej Huty, Kraków

- Medycyna Weterynaryjna, Lublin

- Oecologia, Berlin

- Parki Narodowe i Rezerwaty Przyrody, Białowieża

- Polskie Archiwum Weterynaryjne, Warszawa

- Polskie Pismo Entomologiczne, Wroclaw

- Prace i Materiały Muzeum Archeologicznego i Etnograficznego w Eodzi, Seria Archeologiczna,' Łódź

- Przegląd Zoologiczny, Wrocław

- Roczniki Naukowe Zootecheniki. Warszawa

- Scientifur, Hilleroed

- Sprawozdania Archeologiczne

- Symposia of the Zoological Society of London, London

- Wiadomości Ekologiczne, Warszawa

- Wiadomości Parazytologiczne, Wroclaw

- Zoologische Abhandlungen Staatliches Museum für Tierkunde Dresden, Dresden

- Der Zoologische Garten, Leipzig

- Książki, books

\section{TITLES OF PAPERS NOT INCLUDED IN PREVIOUS ISSUE FOR 1986}

BRELINSKA R., HOUBEN-DEFRENSE M. P. \& BONIVER J. [Dept. Hist. Embr., Med. Acad., Święcickiego 6, 60-781 Poznań]: Multicellular complexes of thymocytes and different types of thymic stromal cells in the mouse. Cell. Tissue Res., 244, $3: 673-679$.

CYREK K. \& MAROSIK P.: Znalezisko ciosu mamuta z Bełchatowa, woj. Piotrkowskie - A mammoth's tusk from Belchatów, Piotrków province. Pr. Mat. Archeol. Etnograf. Lódź, Ser. archeol. 31 (1984): 29-40 [In Polish with English summ.]. 
DZIĘCIOEOWSKI R. [Dept. Game Manage, Forestry Fac., Warsaw Agric. Univ., Rakowiecka 26/30, 02-528 Warszawa] : Vorkommen, Häufigkit und Wilddichte im europäischen Teil der UdSSR und in Polen. In "Das Elchwild. Naturgeschichte, Okologie, Hege und Jagd des europäischen Elches" Eds J. Rülcker \& F. Stalfelt, Verl. P. Parey, Hamburg, Berlin : 267-277.

FRĄCKOWIAK H. (1) [Dept. Appl. Zool., Agric. Acad., Al. Wojska Polskiego 71 c, 60-625 Poznań]: Tętnice glowy u mundżaka chińskiego (Muntiacus reevesi Ogilby, 1838) - Arteries of Chinese muntjak head (Muntiacus reevesi Ogilby, 19838). Roczn. Akad. Roln. Poznan, 176 zootechn. 34: 49-56 [In Polish with English and Russ. summ.].

FRĄCKOWIAK H. (2): Tętnice głowy u niali grzywiastej (Tragelaphus angasi Gray, 1849) - Arteries of head in Tragelaphus angasi Gray, 1849. Roczn. Akad. roln. Poznan 176, zootechn. 34: 39-47 [In Polish with English and Russ. summ.].

GABRYS G. \& HAITLINGER R. [Dept. Zool. Agric. Acad., Cybulskiego 20, 50-205 Wrocław]: New and rare mites (Acari: Calyptostomatidae, Erythraeidae, Trombidiidae) for the fauna of Poland. Pol. Pismo entomol. 56, 2: 471-474.

GLIŃSKA B. (1), see GOSCICKA D. \& GLIŃSKA B. (1).

GLIŃSKA B. (2), see GOSCICKA D. \& GLIŃSKA B. (2)

GLINSKA B. (3), see GOSCICKA D. \& GLIŃSKA B. (3).

GLUCZAK J., see SEAWOMIRSKI J. \& GLUCZAK J.

GODULA G.: Zwierzęcy material kostny ze stanowiska 76 w Nowej Hucie-Branicach - [Animal bone remnants from Nowa Huta-Branice, Site No 76]. Mat, Archeol. Nowej Huty, 10:103-105 [In Polish].

GOSCICKA D. \& GLIŃSKA B. (1) [Dept. Norm. \& Topograph. Anat., Pomeranian Med. Acad., Powstańców Wlkp. 72, 10-111 Szczecin]: Inwolucja grasicy u płodów norki (Mustela vison L.) - Thymus involution in mink fetuses (Mustela vison L.). Pol. Archwm wet. 25, 4: 117-119 [In Polish with English and Russ. summ.].

GOSCICKA D. \& GLIŃSKA B. (2): Pień ramienno-glowowy u norki (Mustela vison L.) - Brachiocephalic trunk in mink (Mustela vison L.). Pol. Archwm. wet. 25, $4: 101-109$ [In Polish with English and Russ. summ.].

GOSCICKA D. \& GLINSKA B. (3) : Skeletotopia luku aorty u świni i jej plodów - Sceletotopy of the aorta in adult pig and its fetuses. Pol. Archwm wet. 25, 4 : $111-115$ [In Polish with English and Russ. summ.].

GOSCICKA D. \& SPOZ S.: Badania metryczne tętnic gruczolu krokowego psa (Canis familiaris L.) - Measuring investigations of the arteries of the prostatae in dog. Pol. Archwm wet. 25, 4: 93-99 [In Polish with English and Russ. summ.].

GRACZYK R. [Inst. Appl. Zool., Agric. Acad., Al. Wojska Polskiego 71 c, 60-625 Poznań]: Restytucja bobra europejskiego (Castor fiber Linnaeus, 1758) w Wielkopolsce - introdukcja, liczebność i rozprzestrzenienie - [Restitution of the beaver (Castor fiber Linnaeus, 1758) in Wielkopolska region - introduction, number and distribution]. Kron. Wielkop. 4 (1985) : 107-134 [In Polish].

GROTTEL K., ZIMNY R. \& JAKIELSKA D. [Dept. Neurobiol., Acad. Physical Educ., Bema 10, 61-55 Poznań]: The nucleus „,k" of Meessen and Olszewski efferents to the cerebellar paramedian loble: a retrograde tracing histochemical (HRP) study in the rabbit and the cat. J. Hirnforsch. 27, 3: 305-322 [German summ.].

GROTTEL K. see, ZIMNY R. et al.

HAITLINGER R. (1) [Dept. Zool., Agric. Acad., Cybulskiego 20, 50-205 Wroclaw] : Myocoptidae Gunther, 1942 (Acari, Astigmata) Polski - Myocoptidae Gunther, 1942 (Acari, Astigmata) of Poland. Pol. Pismo entomol. 56, 2: 389-422 [In Polish]. HAITLINGER R. (2): Psorergates polonicus sp.n. (Acari, Prostigmata, Psorergatidae) from Pitymys subterraneus (de Sel. Long.). Pol. Pismo entomol. 56, 2 :

HAITLINGER R. (3): Trichoecius widawaensis sp.n. (Acari, Astigmata, Myocop- 
tidae) from Apodemus agrarius (Pall.). Pol. Pismo entomol. 56, 423-424.

HAITLINGER R. (4), see GABRYS G. \& HAITLINGER R.

JAKIELSKA D., see GROTTEL $\mathrm{K}$. et al.

JEZIERSKI T., see. KOWNACKI M. et al.

KIELAN-JAWOROWSKA Z. \& TROFIMOW B. [Paleobiol, Inst., P.A. Sci., Zwirki i Wigury 93, 02-089 Warszawa]: Endocranial cast of the Cretaceous eutherian mammal Barunlestes. Acta palaeont. pol. 31, 1-2: 137-144 [Polish summ.].

KNASIECKA V. [Dept. Anim. Anat., Agric. Acad., Al. Wojska Polskiego 71 c, 60-625 Poznań]: Tętnice łuku aorty u piżmaka (Ondatra zibethica L., 1766) - The aortic at musk rat (Ondatra zibethica L., 1766). Roczn. Akad. roln. Poznań 176, zootechn. 34: 83-92 [In Polish with English and Russ. summ.].

KOTECKI A., see ZIMNY R. et al.

KOWNACKI M. \& ZUK B. (1) [Inst. Gen. \& Anim. Breeding, P.A. Sci., Jastrzębiec, 05-551 Mrokow]: Effects of population size on realized heritability of postweaning gain and on genetic correlation with 21- and 42- day weight in mice. Gen. pol. 27, 1-2: 103-125 [Polish and Russ. summ.].

KOWNACKI M. \& ŻUK B. (2): Population size and response to selection for postweaning weight gain in mice. Gen. pol. 27, 1-2: 99-111: [Polish and Russ. summ.].

KOWNACKI M., ŻUK B. \& JEZIERSKI T.: Reproduction in mouse populations of various sizes selected for postweaning growth Gen. pol. 27, 1-2: 127-136 [Polish and Russ. summ.].

KUBIK J., see ZIOEO T. \& KUBIK J.

MAROSIK P., sEe CYREK K. \& MAROSIK P.

SŁAWOMIRSKI J. \& GLUCZAK J. [Inst. Noninfect. Dis., Agric. Acad., Akademicka 12, 20-033 Lublin]: Budowa i topografia nucleus proprius cornus dorsalis w rdzeniu kręgowym konia - Structure and topography of the nucleus proprius coronus dorsalis in spinal cord of the horse. Pol. Archwm. wet. 25, 4: 131-134 [In Polish with English and Russ. summ.].

SPOZ S., see GOSCICKA D. \& SPOZ S.

ZIMNY R., GROTTEL K. \& KOTECKI A. [Dept. Neurobiol., Acad. Physical Educ., Bema 10, 61-555 Poznań]: Evidence for cerebellar efferents to the ventral lateral geniculate nucleus and the lateral terminal nucleus of the accessory optic system in the rabbit. A morphological study with comments on the organizational features of visuo-oculomotor-trunco-cerebellar loops. J. Hirnforsch. 27, 2: 159-212 [German summ.].

ZIMNY R., see GROTTEL K. et al.

ZIOLO T. \& KUBIK J. [Inst. Nonifec. Dis., Agric. Acad., Akademicka 12, 20-033 Lublin]: Przyczynek do badań nad patologicznymi zmianami aorty u chomika dżungarskiego i rzęsorka rzeczka - Contribution to investigations of pathological changes in the aorta of the dżungarian hamster and water shrew. Annals Univ. M. Curie-Skłodowska C, 38 (1983), 16: 193-198 [In Polish with English and Russ. summ.].

ZUK B., see KOWNACKI M. \& ŻUK B. (1).

ZUKK B. (2), see KOWNACKI M. \& ŻUK B. (2).

ZUK B., see KOWNACKI M. et al.

\section{TITLES OF PAPERS PUBLISHED IN 1987}

AMAROWICZ R., see ZAMOJSKI J. et al.

AULAK W. \& GOSZCZYNSKI J. [Dept. Game Manage., Forestry Fac., Warsatw 
Agric. Univ., Rakowiecka 26/30, 02-528 Warszawa]: Inwentaryzacja populacji kopytnych metoda pędzeń $w$ całych kompleksach leśnych - An inventory of hoofed populations driven through entire forest complexes. Wiad. ekol. 32, 4 (1986): 403-413 [In Polish with English summ.].

BANACH A. (1) [Dept. Zool. \& Ecol., Warsaw Univ., Krakowskie Przedmieście 26-28, 00-927 Warszawa]: Small rodent communities in a complex of forest biotopes. Acta theriol. 32, 14: 229-244 [Polish summ.].

BANACH A. (2), see KOZAKIEWICZ M. et al.

BIEGUSZEWSKI H., see STANISEAWSKA B. et al.

BIELA-JACEK I., see ZABEL M. et al.

BLUSZCZ A., BLASKI M., SEBESTA R., SZILMAN P. [Dept. Zool., Silesian Univ., Bankowa 9, 40-007 Katowice] : Helmintofauna drobnych gryzoni (Rodentia) kilku miejscowości okręgu katowickiego - Helminths in rodents (Rodentia) from several villages of Southern provinces of Poland. Acta biol. siles. USI. 6, 23 : 127-129 [In Polish with English and Russ. summ.].

BLASKI M., see BLUSZCZ A. et al.

BOCHENSKI Z., NADACHOWSKI Z. \& WOLSAN M. [Inst. Syst. \& Exp. Zool., P.A.Sci., Sławkowska 17, 31-016 Kraków]: Pochówki zwierzęce z cmentarzyska grupy Masłomęckiej w Mroczynie (Młodszy okres wplywów Rzymskich, południowo-wschodnia Polska) - Animal burials from the cemetery of the Masłomęcz group at Mroczyn (Late Roman period, South-Eastern Poland). Spr, archeol. 39: 321-329 [In Polish with English summ.].

BOGDANOWICZ W. \& RUPRECHT A. L. [Mammals Res. Inst., P.A.Sci., 17-230 Bialowieża]: Przypadki stwierdzeń szopa pracza, Procyon lotor (Linnaeus, 1758) w Polsce - Occasional occurrence of the raccoon, Procyon lotor (Linnaeues, 1758) in Poland. Prz. zool. 31, 3: 375-383 [In Polish with English summ.].

BORATYNSSI Z., see STRZAŁKA B. et. al.

BUJAK A., JASTRZĘBSKI M., MILART Z. \& ZIOEO I. [Dept. Anim. Anat., Agric. Acad., Akademicka 12, 20-934 Lublin] : Jądra móżdżku piesaka (Alopex lagopus) The nuclei of the cerebellum of Alopex lagopus. Annls Univ. M. Curie-Skłodowska DD, 39 (1984), 3: 19-27 [In Polish with English and Russ. summ.].

BUJAK A., see MILART Z. et al.

BUCHALCZYK T., see JAKUBIEC Z. \& BUCHALCZYK T.

CABON-RACZYNSKA K., see KRASINSSKA M. et al.

CABON-RACZYNSKA K., KRASIŃSKA M., KRASIŃSKI Z. \& WOJCIK J. M. [Mammals Res. Inst., P.A.Sci., 17-230 Białowieża]: Rhythm of daily activity and behavior of European bison in the Białowieża Forest in the period without snow cover. Acta theriol. 32, $21: 335-372$ [Polish summ.].

CEBULSKA B. [Dept. Syst. Zool,, A. Mickiewicz Univ., Fredry 10, 61-701 Poznań] : Analiza wieku i plci niektórych gatunków Micromammalia na podstawie materialu wypluwkowego plomykówki - Tyto alba guttata - An analysis of age and sex in some species of small mammals (Micromammalia) based on pellets of Tyto alba guttata. Bad. fizjogr. Pol. zach. C, 35: 85-108 [In Polish with English summ.].

CHMIELEWSKI S., see ŁAKOMY M. et al.

CHOLEwA B. [Dept. Syst. Zool., A. Mickiewicz Univ., Fredry 10, 61-701 Poznań] : Badania nad fauną nietoperzy (Chiroptera) zimujących w Poznaniu - Studies on bats (Chiroptera) wintering at Poznan. Bad. fizjogr. Pol. zach. C, 36: 5-26 [In Polish with English summ.].

CZERWONKA M., see SAWICKA-KAPUSTA K., CZERWONKA M. \& ZAKRZEWSKA $M$.

CZYZEWSKA T. [Dept. Palaeozool., Wroclaw Univ., Sienkiewicza 21, 50-355 Wroslaw]: Historia rodzaju Alces Gray - History of the genus Alces Gray. Prz. zool. 31, 2: 195-202 [In Polish with English summ.]. 
DEMIASZKIEWICZ A. W. (1) [Inst. Parasit. P.A.Scl., Pasteura 3, 00-973 Warszawa]: Elaphostrongylus cervi (Cameron, 1931) in European red deer (Cervus elaphus) in Poland. Acta parasit. pol. 32, 2: 171-178 [Polish summ.].

DEMIASZKIEWICZ A. W. (2): Niektóre aspekty epizootiologii elaphostrongylozy jeleni w Puszczy Białowieskiej - Some aspects of epizootiology of elaphostrongylosis in red-deer in the Bialowieża forest. Med. wet. 43, 4: 208-211 [In Polish with English and Russ. summ.].

DEMIASZKIEWICZ A. W. (3): Skład gatunkowy oraz ekstensywność inwazji jeleniowatych $\mathrm{w}$ wybranych lowiskach przez nicienie $\mathrm{z}$ rodziny Protostrongylidae - The species composition and extensiveness of Protostrongylid nematods invasion in cervids on selected hunting grounds. Wiad. parazyt. 33, 1: 57-62 [In Polish with English summ.].

DEMIASZKIEWICZ A. W. (4), see DROŻZ J. et al.

DROŻZ J., LACHOWICZ J., DEMIASZKIEWICZ A. W. \& SULGOSTOWSKA A. [Inst. Parazyt., P.A.Sci., Pasteura 3, 00-973 Warszawa]: Abomasum nematodes in field and forest roe deer Capreolus capreolus (L.) over the yearly cycle. Acta parasit. pol. 32, $4: 339-348$ [Polish summ.].

DROŻDZ J., see KINGSTON N. et al.

DZIURDZIK B. [Dept. Syst. \& Exp. Zool. P.A.Sci., Slawkowska 17, 31-016 Kraków]: Budowa histologiczna włosów - podstawą do wyznaczania nowych stanowisk występowania smużki, Sicista betulina (Pallas, 1748) w Polsce - New localities of birch mouse, Sicista betulina (Pallas, 1778) in Poland, discovered by histological analysis of hairs. Prz. zool. 31, 4: 527-532 [In Polish with English summ.].

FEDYK S. \& LENIEC H. [Lab. Gen. \& Evol. Biol., Dept., Biol., Warsaw Univ., Branch Białystok, Sosnowa 64, 15-887 Białystok]: Genetic differentiation of Polish populations of Sorex araneus L. I. Variability of autosome arm combinations. Folia biol. 35, 1-2: 57-68 [Polish and Russ. summ.].

FEDYK S., see LENIEC H. et al.

FLIEGER S., see STRZAEKA B. et al.

GAWROŃSKA B., see SZTEYN S. et al.

- GĄSIENICA-BYRCYN W. [Mus. Tatra National Park, 34-500 Zakopane] : Kozica - żywy symbol Tatr - [Chamois - the living symbol of Tatra Mountains] KAW, Wrocław, 46 pp. [In Polish].

GĘBCZYŃSKA Z., SOETYS H. \& SIENKIEWICZ M. [Dept. Biol., Warsaw Univ. Branch Białystok, Sosnowa 64, 15-887 Białystok] : Food composition in striped field mice living at localities of various degrees of urban development. Acta theriol. 32, $20: 325-330$ [Polish summ.].

GEBCZYNSKI M. \& TOMASZEWSKA-GUSZKIEWICZ K. [Dept. Biol., Warsaw Univ., Branch Białystok, Sosnowa 64, 15-887 Białystok]: Genetic variability in the European bison. Biochem. Syst. \& Ekol., 15, 2: 285-288.

GIERYNG D., see MACIEJEWSKI R. et al.

GEOWACINSKI Z. \& PROFUS P. [Res. Centre Protect. Nat. \& Nat. Resources, P.A.Sci., Lubicz 46, 31-512 Krak6w]: Jeszcze jedno stwierdzenie tchórza stepowego, Mustela eversmanni Lesson, 1827, w Polsce - Next record of the Steppe polecat Mustela eversmanni Lesson, 1812, in Poland. Prz. Zool. 31, 4: 523-526 [In Polish with English summ.].

GEUCHOWSKA B., see MACIEJEWSKI R. et al.

GONET K. \& KOZŁOWSKI J. [Inst. Environment. Biol., Jagiell. Univ., Oleandry 2a, 30-063 Krakbw]: The influence of ambient temperature on the rate of lead elimination in the laboratory mouse, Mus musculus L. Ekol. pol. 35, 2: 373-383 [English and Polish summ.].

GOSZCZYNSKI J. \& PIEATOWSKI T. [Dept. Wildl. Manage., Forestry Fac., Warsaw Agric. Univ., Rakowiecka 26/30, 02-528 Warszawa]: Diet of common buz- 
zards (Buteo buteo L.) in the nesting period. Ekol. pol. 34, 4 (1986): 655-667 [English nad Polish summ.].

GOSZCZYÑSKI J., see AULAK W. \& GOSZCZYŃSKI J.

GORECKI A. (1), see SAWICKA-KAPUSTA K., GORECKI A. \& LANGE R. GORECKI A. (2), see SAWICKA-KAPUSTA K. et al.

GROMADZKA-OSTROWSKA J. (1), see JAKUBOW K. \& GROMADZKA-OSTROWSKA J. (1).

GROMADZKA-OSTROWSKA J. (2), see JAKUBOW K. \& GROMADZKA-OSTROWSKA J. (2).

HAITLINGER R. (1) [Dept. Zool., Agric. Acad., Cybulskiego 20, 50-205 Wroclaw]: Description of female Trichoecius widawaensis Haitlinger, 1986 (Acari, Astigmata, Myocoptidae). Pol. Pismo entomol. 57, 3: 597-598 [Polish summ.].

HAITLINGER R. (2): Myobia (Myobia) annae sp.n. (Acari, Prostigmata, Myobiidae) from Apodemus mystacinus Danford, Alston (Rodentia, Muridae) from Greece. Pol. Pismo entomol. 57, $3:$ 535-537.

HAITLINGER R. (3): Psorergates owalaensis sp.n. (Acari, Prostigmata, Psorergatidae) from Crocidura suaveolens (Pall.). Pol. Pismo entomol. 57, 3: 539-540.

HAITLINGER R. (4) : Roztocze (Acari) nowe lub rzadkie w faunie Polski uzyskane $\mathrm{z}$ drobnych ssaków i owadów - The mites (Acari) new or little known in the fauna of Poland, taken from small mammals and insects. Fragm. faun. 30, 18: 313-320 [In Polish with English ad Russ. summ.].

HAITLINGER R. (5) : Stawonogi (Siphonaptera, Anoplura, Acari) występujące w Polsce na Crocidura leucodon (Hermann, 1780) (Mammalia, Insectivora) - Arthropods (Siphonaptera, Anoplura, Acari) occurring in Poland on Crocidura leucodon (Herman, 1780) (Mammalia, Insectivora). Wiad. parazyt. 33, 2: 221-228 [In Polish with English summ.].

HAITLINGER R. (6): Stawonogi (Siphonaptera, Anoplura, Acari) występujące w Polsce na Spermophilus suslicus (Gueldenstaedt, 1770) (Mammalia, Rodentia) Arthropods (Siphonaptera, Anoplura, Acari) occurring in Poland on Spermophilus suslicus (Gueldenstaedt, 1770) (Mammalia, Rodentia). Wiad. parazyt. 33, $6: 701-705$ [In Polish with English summ.].

HARMATA W. [Inst. Environ. Biol., Jagiell. Univ., Karasia 6, 30-060 Kraków] : The frequency of winter sleep interruptions in two species of bats hibernating in limestone tunnels. Acta theriol. 32, $21: 331-332$ [Polish summ.].

HEREC S. (1), see MILART Z. \& HEREC S.

HEREC S. (2), see MILART Z. et al.

JABEONSKI B., KRZEMIŃSKI W. \& ZDZITOWIECKI K. [Inst. Zool., P.A.Sci., Wilcza 64, 00-679 Warszawa]: Distribution and number of fur seals, Arctocephalus gazella (Peter, 1875) of King George Island (South Shetlands). Acta zool. cracov., $30,9: 119-136$ [Polish summ.].

JAKUBIEC Z. \& BUCHALCZYK T. [Nature Protect. Res. Centre, P.A.Sci., Podwale 75, 50-449 Wrocław]: The brown bear in Poland: its history and present numbers. Acta theriol. 32, $17: 289-306$ [Polish summ.].

JAKUBOW K. \& GROMADZKA-OSTROWSKA J. (1) [Physiol. Lab., Warsaw Zool. Garden, Ratuszowa $1 / 3,03-461$ Warszawa]: Changes in nonspecific immunity factor in some Equidae, Camelidae and Capridae species. Comp. Biochem. Physiol. 86 A, $4: 633-637$.

JAKUBOW K. \& GROMADZKA-OSTROWSKA J. (2): Twenty-four hour changes in lysozyme levels, total plasma protein concentration, white blood cell count and numbers of lymphocytes and granulocytes in the peripheral blood of chinchillas Chinchilla laniger. M. and rabbits Oryctolagus cuniculus L. Comp. Biochem Physiol. 86 A, $1: 109-112$.

JANECZKO K. [Dept. Neuroanat., Inst. Zool., Jagiell. Univ., Karasia 6, 30-060 Kraków]: Difference between the distribution of the proliferative activity of 
neuroglial and mesodermal cells within the dorsal part of the rat cerebral hemisphere during postnatal development. Folia biol. $35,1-2: 13-22$ [Polish and Russ. summ.].

\section{JASTRZEBBSKI M., see BUJAK A. et al.}

JEDRZEJEWSKA B. [Mammals Res. Inst., P.A.Sci., 17-230 Białowieża]: Reproduction in weasels Mustela nivalis in Poland. Acta theriol. 32, 31: 493-496. JUSZCZAK G., see SAWICKA-KAPUSTA K. et al.

KALETA T. \& LEWANDOWSKA A. [Inst. Anim. Breed. \& Prod. Techn. Warsaw Agric. Univ., Przejazd 4, 05-840 Brwinów]: The escape distance in farm silver foxes with regard to cronism problem. Scientifur 11, 3: 187-189.

KAŁUZA T. [Dept. Zool., A. Mickiewicz Univ., Fredry 10, 61-701 Poznań]: Stanowisko orzesznicy Muscardinus avellanarius (Linnaeus, 1758) w Wielkopolsce Locality of common dormous Muscardinus avellanarius (Linnaeus, 1758) in the Wielkopolska district. Prz. zool. 31, 2: 215-218 [In Polish with English summ.].

KASPERCZYK B. [Inst. Gen. \& Anim. Breed., P.A.Sci., St. Popielno, 12-222 Wejsuny]: Rozprzestrzenianie się bobra (Castor fiber L.) w Europie w XX wieku The expansion of beaver (Castor fiber L.) in Europe in 20th century. Prz. zool., 31, 2 : 181-193 [In Polish with English summ.].

KIELAN-JAWOROWSKA Z., DASHZEVEG D. \& TROFIMOV B. A. [Plaeobiol. Inst., P.A.Sci., Żwirki i Wigury 93, 02-089 Warszawa]: Early Cretaceous multituberculates from Mongolia and a comparison with Late Jurassic form. Acta palaeont. pol. $32,1-2: 3-47$.

KINGSTON N., DROŻDZ J. \& RUTKOWSKA M. [Inst. Parazyt. P.A.Sci., Pesteura 3, 00-973 Warszawa]: Występowanie świdrowców z rodzaju Trypanosoma u przeżuwaczy wolno żyjących w Polsce - Occurrence of trypanosomes of genus Trypanosoma at wild ruminants in Poland. Wiad. parazyt. 33, 1: 219-220 [In Polish with English summ.].

KITA J., see SYSA P. et al.

KLEVEZAL G. A. \& PUCEK Z.: Growth layers in tooth cement and dentine of European bison and its hybrids with domestic cattle. Acta theriol. 32, 9: 115-128 [Polish summ.].

KOBRYN H., see MOSKALEWSKA-LASOTA A. et al.

KOBRYNCZUK F. \& KRASINSKA M. [Dept. Anim. Anat., Warsaw Agric. Univ., Nowoursynowska 166, 02-766 Warszawa]: Taxonomic studies on skulls of European bison and domestic cattle hybrids. Acta theriol. 32, 12: 203-218 [Polish summ.]. KORZENIOWSKI W., see ZAMOJSKI J. et al.

KOTEJA P. (1) [Dept. Anim. Ecol., Inst. Environment. Biol., Jagiell. Univ., Karasia $6,30-060$ Kraków]: On the relation between basal and maximum metabolic rate in mammals. Comp. Biochem Physiol, A 87, 1: 205-208.

KOTEJA P. (2), SEe OKARMA H. \& KOTEJA P.

KOTIK T., see WITKOWSKA A. \& KOTIK T.

KOWALSKI J. (1), see NIEDŹWIADEK S. et al. (1).

KOWALSKI J. (2), see NIEDŻWIADEK S. et al. (2).

- KOWALSKI K. (1) [Inst. Syst. \& Exp. Zool., P.A.Sci., Sławkowska 17, 31-016 Kraków] : A history of mammalogy in Poland. In "An International History of Mammalogy", Ed. K. B. Sterling, Vol. I : 25-59, One World Press, Maryland.

KOWALSKI K. (2): Pleistocene rodents from the Nubian Desert in Egypt. African Small-Mammal Newsletter 9: 16-17.

KOZAKIEWICZ A. (1) [Dept. Zool. \& Ecol., Inst. Zool., Warsaw Univ., Krakowskie Przedmieście 26/28, 00-921 Warszawa]: Spatial distribution and interspecific interactions in small rodent community of a lake coastal zone. Acta theriol. 32, 26: 433-447 [Polish summ.]. 
KOZAKIEWICZ A. (2), see KOZAKIEWICZ M. et al.

KOZAKIEWICZ M.; KOZAKIEWICZ A. \& BANACH A. [Dept. Zool. \& Ecol. Inst. Zool., Warsaw Univ., Krakowskie Przedmieście 26/28, 00-927 Warszawa] : Effect of environmental conditions on the character of spatial interactions among three small rodent species. Bull. Pol. Acad. Sci., Biol. Sci., 35, 7-9: 181-188 [Russ. summ:].

KOZAKIEWICZ M. \& SZACKI J. : Drobne ssaki środowisk izolowanych - wyspy na lądzie czy tylko populacje wyspowe? - Small mammals of isolated habitats : islands on the mainland or only island populations ? Wiad. ekol. 33, 1: 31-45. [In Polish with English summ.].

KOZŁOWSKI J. \& WOJCIK A. [Inst. Environment. Biol., Jagiell. Univ. Oleandry 2a, 30-063 Kraków]: Accumulation and elimination of orally administered lead in laboratory mice: experimental studies and a simple mathematical model. Ekol. pol. 35, 2: 355-371 [English and Polish summ.].

KOZLOWSKI J., see GONET K. \& KOZLOWSKI J.

KRASINSKA M., CABOŃ-RACZYŃSKA K. \& KRASIŃSKI Z. [Mammals Res. Inst., P.A.Sci., 17-230 Białowieża]: Strategy of habitat utilization by European bison in the Białowieża Forest. Acta theriol. 32, 11: 147-202 [Polish summ.].

KRASINSKA M. (1), see CABON-RACZYŃSKA K. et al.

KRASINSKA M. (2), see KOBRYNCZUK F. \& KRASIŃSKA M.

KRASIŃSKI Z. (1) [Białowieża Nat. Park, 17-230 Białowieża]: Hodowla rezerwatowa żubrów w Puszczy Boreckiej - Reserve breeding of European bison in Borecka Forest. Parki nar. Rez. przyr. 7 (1986), 2: 73-79 [In Polish with English summ.].

KRASINSKI Z. (2), CABOŃ-RACZYŃSKA K. et al.

KRASINSKI Z. (3), see KRASIŃSKA M. et al.

KRZEMIŃSKI W., see JABEOŃSKI B. et al.

KUKUREWICZ T. [Nat. Hist. Museum, Wroclaw Univ., ul. Sienkiewicza 21, 50-335 Wroclaw]: Nowe dane o występowaniu podkowca małego (Rhinolophus hipposiof Lesser Horseshoe Bat (Rhinolophus hipposideros Bechstein, 1800) in East Sudets. Prz. zool., 31, 3: 365-370 [In Polish with English summ.].

LACHOWICZ J., see DROZZDŹ J. et al.

LANGE R., see SAWICKA-KAPUSTA K., GORECKI A. \& LANGE R.

LASOTA-MOSKALEWSKA A., KOBRYŃ H. \& SWIEŻYNSKI K. [Ateliers Conserv. Cultural Propert., Senatorska 14, 00-950 Warszawa]: Changes in the size of the domestic and wild pig in the territory of Poland from the Neolithic to the Middle Ages. Acta theriol. 32, 5: 51-81 [Polish summ.].

LENIEC H., FEDYK S. \& RUPRECHT A. L. [Lab. Gen. Evol. Biol., Warsaw Univ., Branch Bialystok, Sosnowa 64, 15-887 Bialystok]: Chromosomes of some species of Vespertilionid bats. New data on the plecotine bats. Acta theriol. 32, 18: 307-314 [Polish summ.].

LENIEC H., see FEDYK S. \& LENIEC H.

LEWANDOWSKA A., see KALETA T. \& LEWANDOWSKA A.

LOREK O., see STANISEAWSKA B. et al.

ŁAKOMY M., SZATKOWSKA C. \& CHMIELEWSKI S. [Dept. Anim. Anat., Inst. Fund. Vet. Sci., Agric. \& Techn. Acad., Kortowo, 10-957 Olsztyn]: The adrenergic and $\mathrm{AChE}$-positive nerves in pig vagina. Anat. Anz. 164, 1: 39-46.

MACIEJEWSKI R., GEUCHOWSKA B. \& GIERYNG D. [Dept. Norm. Anat., Med. Acad., 22 Lipca 1, 20-074 Lublin]: Niektóre pomiary serca u koczkodana zielonego 
(Cercopithecus aetiops) oraz ich zależności między sobą i wymiarami zewnętrznymi ciała - Some heart measuremens of Cercopithecus aetiops and their dependence on one another and external body dimensions. Annls Univ. M. Curie-Skłodowska D, 38 (1983), 42: 315-321 [In Polish with English and Russ. summ.].

MARKOWSKI J. \& SIKORSKI M. [Dept. Comp. Anat., Anim. Ecol., Łódź Univ., Banacha 12/16, 90-237 Łódź]: Zastosowanie cech niemetrycznych w badaniach populacyjnych - Use of non-metrical traits in population study. Prz. zool. 31, 1: 7-23 [In Polish with English. summ.].

MAZURKIEWICZ M. \& RAJSKA-JURGIEL E. [Inst. Ecol., P.A.Sci., Dziekanów Leśny, 05-092 Łomianki]: Numbers, species composition and residency of a rodent community in forest and field-forest ecotones. Acta theriol. 32, 25: 413-432 [Polish summ.].

MICHALAK I. [Mammals Res. Inst., P.A.Sci., 17-230 Białowieża]: Growth and postnatal development of the European water shrew. Acta theriol. 32, $16: 261-288$ [Polish summ.].

MIELCZAREK M., see SAWICKA-KAPUSTA K. et al.

MILART Z., see BUJAK A. et al.

MILART Z. \& HEREC S. [Dept. Anim. Anat., Agric Acad., Akademicka 12, 20-934 Lublin]: Jądro Onufa w rdzeniu kręgowym piesaka (Alopex lagopus) - Onuf's nucleus in the spinal cord of the Alopex lagopus. Annls Univ. M. Curie-Skłodowska DD, 39 (1984), 1: 1-7 [In Polish with English and Russ. summ.].

MILART Z., ZIOEO I., HEREC S. \& BUJAK A.: Topografia i budowa jądra ruchowego n. dodatkowego (nucl. motorius n. accessorii), jądra przywspółczulnego n. językowo-gardlowego i błędnego (nucl. parasympathicus n. glossopharyngei et vagi), jądra dwuznacznego (nucl. ambiguus) piesaka (Alopex lagopus) - Topography and cytostructure of nucl. motorius n. accessorii, nucl. parasympathicus n. glossopharyngei et vagi and nucl. ambiguus in Alopex lagopus. Annls Univ. M. Curie-Skłodowska DD, 39 (1984), 2: 9-17 [In Polish with English and Russ. summ.].

MISKOWIAK B. [Dept. Hist. \& Embryol., med. Acad., Swięcickiego 6, 60-781 Poznań]: Studies on hypothalamo-pituitary corticoliberin system. I. Localization of corticotropin-releasing factor (CRF) and neurophysin-immunoreactive neurons in the mongolian gerbil (Meriones unguiculatus). Acta anat. 128, 1: 71-75.

NADACHOWSKI A., see BOCHEŃSKI Z. et al.

NIEDZWIADEK S., KOWALSKI J. \& PALIMAKA-RAPACZ G. (1) [Inst. Zootechn., Dept. Fur Anim. Breed., 32-083 Balice n. Kraków]: A study on feeding silage to nutria I. Nutria growth and feed utilization. Scientifur 11, 3:223-227.

NIEDZWIADEK S., KOWALSKI J. \& PALIMĄKA-RAPACZ G. (2): A study on feeding silage to nutria. II. Fur value. Scientifur 11, 3:228-232.

NOWOSAD A. \& SAEATA-PILACINSKA B. [Dept. Syst. Zool., A. Mickiewicz Univ., Fredry 10, 61-701 Poznańl: Nietoperze (Chiroptera) w pokarmie plomykówki, Tyto alba guttata (C. L. Brehm, 1831) - Bats (Chiroptera) in the food of the barn owl, Tyto alba guttata (C. L. Brehm, 1831). Prz. zool. 31, 2: 221-230 [In Polish with English summ.].

OKARMA H. \& KOTEJA P. [Dept. Anim. Ecol., Jagiell. Univ., Karasia 6, 30-060 Kraków]: Basal metabolic rate in the gray wolf in Poland. J. Wildl. Manage. 51, 4: $800-801$.

OLECH W. [Dept. Appl. Anim. Gen., Inst. Biol. Basis of Animal Breed., Warsaw Agric. Univ., Przejazd 4, 05-840 Brwinówl: Analysis of inbreeding in European bison. Acta theriol. 32, 22: 373-387 [Polish summ.].

PALIMĄKA-RAPACZ G. (1), see NIEDŹWIADEK S. et al. (1).

PALIMĄKA-RAPACZ G. (2), see NIEDŻWIADEK S. et al. (2).

PARUSEL J. B. [Babia Góra Nat. Park, 34-123 Zawoja]: Tropienie niedźwiedzia Ursus arctos w Babiogórskim Parku Narodowym - Tracking a brown bear, 
Ursus arctos, in the Babia Góra National Park. Chrońmy Przyr. ojcz. 43, 4: 61-64 [In Polish].

PIATKKOWSKA K. \& WEINER J. [Dept. Anim. Ecol., Jagiell. Univ., Karasia 6, 30-060 Kraków]: Maximum rate of energy assimilation in the bank vole. Acta theriol. 32, 4: 45-50 [Polish summ.].

PIEATOWSKI T., see GOSZCZYNSKI J. \& PIEATOWSKI T.

PROFUS P., see GLOWACIŃSKI Z. \& PROFUS P.

PUCEK Z., see KLEVEZAL G. K. \& PUCEK Z.

RACHOWIAK P. [Dept. Syst. Zool., A. Mickiewicz Univ., Fredry 10, 61-701 Poznań] : Kilka spostrzeżeń na temat struktury płci, i wieku oraz rozrodezości nornika pólnocnego, Microtus oeconomus (Pallas, 1776) na torfowisku wysokim w Chlebowie - Some remarks on sex, age structure and reproductiveness of the root vole, Microtus oeconomus (Pallas, 1776) in Chlebowo high peatbog. Prz. zool. 31, 2: 209-213 [In Polish with English summ.].

RAJSKA-JURGIEL E., see MAZURKIEWICZ M. \& RAJSKA-JURGIEL E.

ROMANKOW-ZMMUDOWSKA A. [Inst. Plant Protect, Miczurina 20, 60-318 Poznań] : Występowanie nornika polnego (Microtus arvalis Pall.) w uprawach roślin motylkowych i trawach nasiennych w Polsce w $1982 \mathrm{r}$. - Occurrence of common vole (Microtus arvalis Pall.) in fields of Papilionacae and seed grasses in Poland in 1982. Biul. I.O.R. 68 : 325-329 [In Polish with English and Russ. summ.].

RUPRECHT A. L. (1) [Mammals Res. Inst. P.A.Sci., '17-230 Bialowieża] : Lew jaskiniowy, Panthera spelaea (Goldfuss, 1810), nowym gatunkiem w faunie ssaków kopalnych Bialostocczyzny - Cave lion, Panthera spelaea (Golgfuss, 1810), a new species in the fossil fauna of mammals in the Bialystok region. Prz. zool. 31, 2: 203-208 [In Polish with English summ.].

RUPRECHT A. L. (2): Klucz do oznaczenia żuchw nietoperzy fauny Polski A key for mandible identification of Polish bats. Prz. zool., 31, 1: 89-105 [In Polish with English summ.].

RUPRECHT A. L. (3), see BOGDANOWICZ W. \& RUPRECHT A. L.

RUPRECHT A. L. (4), see LENIEC H. et al.

RUPRECHT A. L. \& SZWAGRZAK A.: Extreme Varianten des $\mathbf{M}^{2}$ und $\mathbf{M}^{3}$ der Nordischen Weühlmaus (Microtus oeconomus Pallas) in Polen (Mammalia, Rodentia, Microtidae). Zool. Abh. Mus. Tierkd. Dresden 43, 3: 21-23 [English summ.].

RUTKOWSKA M., see KINGSTON N. et al.

RZEBIK-KOWALSKA B. [Inst. Syst. \& Exp. Zool., P.A.Sci., Slawkowska 17, 31-016 Kraków]: The genus Crocidura in Algeria. Afr. Small Mammal Newslet. 9: 11. SAŁATA-PIŁACIŃSKA B., see NOWOSAD A. \& SAŁATA-PIŁACIŃSKA B.

SAWICKA-KAPUSTA K. [Dept. Anim. Ecol., Jagiell. Univ., Karasia 6, 30-060 Kraków]: Pathways of heavy metals in components of a forest ecosystem. Preface Ekol. pol. 35, 2: 243-246.

SAWICKA-KAPUSTA K., CZERWONKA M. \& ZAKRZEWSKA M. [Dept. Anim. Ecol., Jagiell. Univ., Karasia 6, 30-060 Kraków]: Effect of orally administerad lead on the postnatal development in laboratory mice. Ekol. pol. 35, 2: 385-397 [English and Polish summ.].

SAWICKA-KAPUSTA K., GORECKI A. LANGE R.: Heavy metals in rodents from polluted forests in southern Poland. Ekol. pol. 35, 2: 345-354 [English and Polish summ.].

SAWICKA-KAPUSTA K., GORECKI A., SWIERGOSZ R., JUSZCZAK G., MIELCZAREK M. \& WOJCIK B. [Dept. Anim. Ecol., Jagiell. Univ., Karasia 6, 30-060 Kraków]: Effect of metabolic rate on the rate of elimination of high and low concentrations of cadium and lead in the bank vole. Ekol. pol. 35, 2: 399-430 [English and Polish summ.]. 
SEBESTA $\cdot R$, see BLUSZCZ A. et al.

SIENKIEWICZ M., see GĘBCZYŃSKA Z. et al.

SIKORSKI M., sEe MARKOWSKI J. \& SIKORSKI M.

SMOCZYŃSKI S., see ZAMOJSKI J. et al.

SOETYS H., see GEBCZYNNSKA $Z$. et al.

SREBRO Z. [Dept. Biol., Inst. Biomorph, Med. Acad., Kopernika 7, 31-034 Kraków]: Sequestration of nuclear material in satelite cells of the circumventricular organs in the rat brain. Folia biol. 35, 1-2: 79-83 [Polish and Russ. summ.]. STANISEAWSKA B., BIEGUSZEWSKI H. \& LOREK O. [Inst. Zootechn., Agric. Techn. Acad., H. Sawickiej 28, 85-084 Bydgoszcz]: Poziom żelaza i calkowita zdolność wiązania żelaza przez białka osocza oraz wybrane wskaźniki krwi z lisów polarnych (Alopex lagopus L,) - The iron level and total iron binding ability of plasma protein and selected blood indicators in polar visens (Alopex lagopus L.). Pol. Archwm wet. 25, 2-3: 213-224 [In Polish with - English and Russ. summ.].

STRZALKA B., BORATYŃSKI Z. \& FLIEGER S. [Inst. Anim. Anat., Agric. Acad., Akademicka 12, 20-033. Lublin]: Budowa i rozmieszczenie przywspółczulnego oraz dwuznacznego jądra nerwu językowo-gardlowego i blędnego $\mathrm{u}$ bizona (Bison bison L.) - The structure and distribution of the parasympatheic and ambiguous nucleus of the glossopharyngeal and vagus nerve in the bison (Bison bison L.). Pol. Archwm wet. 25, 1: 161-167 [In Polish with English and Russ. summ.].

SULGOSTOWSKA A., see DROŻDŻ J, et:al.

SURDYK J., see ZABEL M. et al.

SYSA P., RUBES J. \& KITA J. [Dept. Hist. \& Embryol., Warsaw Agric. Acad., Nowoursynowska $166,02-766$ Warszawa]: Cytogenetyczna analiza stałej linii komórkowej żubra (Bisón bonasus) - Cytogenetic analysis of a long term cell line in European bison (Bison bonasus). Roczn. nauk. zootechn. 12, 2 (1985): 33-39 [In Polish with English, German and Russ. summ.].

SZACKI J. (1) [Inst. Physic. Planning \& Municipal Economy, Krzywickiego 9, 02-078 Warszawa]: Ecological corridor as a factor determining the structure and organization of a bank vole population. Acta theriol. 32, 3: 31-44 [Polish summ, ].

SZACKI J. (2) ; see KOZAKIEWICZ M. \& SZACKI J.

SZATKOWSKA C., see ŁAKOMY M. et al.

SZATKOWSKI E., see SZTEYN S. et al.

SZILMAN P., see BLUSZCZ A. et al.

SZPAKIEWICZ W., see ZALEWSKA-SCHÖNTHALER N. \& SZPAKIEWICZ W.

SZTEYN S., GAWRONSKA B. \& SZATKOWSKA E. [Teachers Train. Coll., Dept. Vertebr. Anat., Zolnierska 14, 10-561 Olsztyn]: Topography and structure of Corpus striatum in Insectivora. Acta theriol., 32, $7:$ 95-105 [Polish summ.].

SZUBARTOWSKA E. \& GROMÝSzKAŁKOWSKA: K. [Dept. Animal Physiol., Inst. Biol., M. Curie Skkłodowska Univ., Akademicka 19, 20-033 Lublin]: Differences in blood cell count in three breeds of rabbit. Folia biol. 35, 1-2: 111-121 [Polish and Russ. summ.].

SZWAGRZAK A., see RUPRECHT A. L. \& SZWAGRZAK A.

SZYMANSKI S. [Inst. Parazyt., P.A.Sci., Pasteura, 3, 00-973 Warszawa] : Seasonal activity of Dermacentor reticulatis (Fabricius, 1794) (Ixodidae) in Poland III. Larvae and nymphs. Acta parasit. pol. 32, 3: 265-280 [Polish summ.].

SZYMECZKO R. [Dept. Physiol \& Anim. Anat., Agric. Techn. Acad., H. Sawickiej 28, 85-084 Bydgoszç] : Zmiany stężenia w surowicy krwi niektórych wskaźników przemiany białkowej $u$ tchórzofretek w okresie postnatalnym - Changes in blood 
serum concentration of some the indices of protein metabolism in hybrids of skunk-and-ferrets in the postnatal period. Med. wet. 43, 8: 493-496 [In Polish with English and Russ. summ.].

SMIEŁOWSKI J. (1) [Inst. Appl. Zool., Agric. Acad., Wojska Polskiego 71c, 60-625 Poznań]: Ablinism in the blue bull or nilgai, Boselaphus tragocamelus (Pallas, 1766). J. Bombay nat. Hist. Soc. $2: 428-429$.

SMIELOWSKI J. (2) : A note on the reproductive biology of the hunter's antelopes of hirola Damaliscus hunteri (Scalter, 1889) in Zoo environment. Zool. Garten 57, $4: 234-240$.

SWIERGOSZ R., see SAWICKA-KAPUSTA K., GORECKI A. et al.

SWIEŻYŃSKI K., see LASOTA-MOSKALEWSKA A. et al.

TOMASZEWSKA-GUSZKIEWICZ K., see GĘBCZYŃSKI M. \& TOMASZEWSKA-GUSZKIEWICZ K.

WEINER J. (1) [Dept. Anim. Ecol., Jagiell. Nniv., Karasia 6, 30-600 Kraków] : Limits to energy budget and tactics in energy investments during reproduction in the Djungarian hamster (Phodopus sungorus sungorus Pallas 1770). Symp. zool. Soc. Lond. $57: 167-187$.

WEINER J. (2): Maximum energy assimilation rates in the Djungarian hamster (Phodopus sungorus). Oecologia (Berlin) 72: 297-302.

WEINER J. 3), see PIĄTKOWSKA K. \& WEINER J.

WEINER J. \& HELDMAIER G. : Metabolism and thermoregulation in two races of Djungarian hamster: Phodopus sungorus sungorus and P. s. campbelli. Comp. Biochem Physiol. 86 A, 4: 639-642.

WITKOWSKA A. \& KOTIK T. [Inst. Anim. Physiol. \& Nutr., P.A.Sci., Meat Soi. Dep., pl. Weyssenhoffa 11, 85-072 Bydogszcz]: Concentrations of creatine, creatinine and phosphorus in skeletal muscles of the European bison. Acta theriol. 32, 13: 219-228 [Polish summ.].

WOLSAN M., see BOCHEŃSKI Z. et al.

WOŁK K. (1) [Nat. Hist. Museum, M. Kopernik Univ., Gagarina 9, 87-100 Toruń] : Nowe stanowisko orzesznicy Muscardinus avellanarius (L.) na Pojezierzu Mazurskim - New localities of common dormouse Muscardinus avellanarius (L:) in: Pojezierze Mazurskie. Prz. zool. 31, 2: 219-220 [In Polish with English summ.].

WOŁK K. (2) : Zając bielak, Lepus timidus L., w Puszczy Knyszyńskiej - Mountain hare, Lepus timidus L., in the Puszcza Knyszyńska. Prz. zool. 31, 3: 371-373 [In Polish with English summ.].

WOŁOSZYN B. [Inst. Syst. \& Exp. Zool., P.A.Sci., Slawkowska 17, 31-016 Kraków]: Pliocene and Pleistocene bats of Poland. Acta palaeont. pol. 32, 3-4: 207-325 [Polish. summ.].

WOJCIK A., see KOZŁÓWSKI J. \& WOJCIK A.

WOJCIK B., see SAWICKA-KAPUSTA K., GORECKI A. et al.

WOJCIK J. M. \& ZIMA J. [Mammals Res. Inst., P.A.Sci., 17-230 Białowieża]: Cytogenetyka ryjówki aksamitnej. Sorex araneus Linnaeus, 1758 - Cytogenetic of the common shrew, Sorex araneus Linnaeus, 1758. Prz. zool. 31, 4: 439-456 [In Polish with English summ.].

WOJCIK J. M., see CABON-RACZYŃSKA K. et al.

ZABEL M., SURDYK J. \& BIELA-JACEK I. [Dept. Hist. Embryol., Med. Acad., Swięcickiego 6, 60-781 Poznań]: Immunocytochemical studies on thyroid parafollicular cells in postnatal development of the rat. Acta anat. 130, 3: 251-256.

ZAKRZEWSKA M., see SAWICKA-KAPUSTA K. et al.

ZALEWSKA-SCHONTHALER N. \& SZPAKIEWICZ W. : Helmintofauna przewodu 
pokarmowego losi i sarn w Puszczy Rominckiej - The helminthofauna of the alimentary tract of elk and roe deer in Romincka Forest. Wiad. parazyt. 33, 1 : 63-65 [In Polish with English summ.].

ZAMOJSKI J., AMAROWICZ R., KORZENIOWSKI W. \& SMOCZYŃSKI S. [Inst. Food Engineering \& Biotechn., Agric. \& Techn. Acad., 10-728 Olsztyn-Kortowo]: Pozostałości chlorowanych węglowodanów w tłuszczu, tkance mięśniowej, wątrobie oraz mózgu dzika, jelenia i sarny - Residues of chlorinated hydrocarbon insecticides in meat, liver and brain of a wild boar, roe deer and a stag. Med. wet. 43, 7: 406-408 [In Polish with English and Russ. summ.].

ZDZITOWIECKI K., see JABŁOŃSKI B. et al.

ZIOEO I. (1), see BUJAK A. et al.

ZIOEO I. (2), see MILART Z. et al.

ZIOMEK J. [Dept. Syst. Zool., A. Mickiewicza Univ., Fredry 10, 61-701 Poznań] : Zmiany w faunie Micromammalia okolic Pulaw w latach 1948-49, 1982-84 Changes of small mammal fauna in Pulawy district in the period 1948-49 and 1982-84. Prz. zool., 31, $4: 533$-551 [In Polish with English summ.].

ZUROWSKI W. \& KAMMLER J. [Inst. Gen. \& Anim. Breed., P.A.Sci., Res. St. Popielno, 12-222 Wejsuny] : Norka amerykańska (Mustela vison Shreber, 1777) w stanowiskach bobrów - American mink (Mustela vison Schreber, 1777) in beaver sites. Prz. zool., 31, 4: 513-521 [In Polish with English summ.].

\section{SUBJECT INDEX ${ }^{1}$}

O. GENERAL

Kowalski - 1 .

\section{EVOLUTION AND GENETICS}

Fedyk \& Leniec; Gębczyński \& Tomaszewska-Guszkiewicz; Kownacki \& Żuk $(1986-1,2)$ : Kownacki et al.;
(1986); Leniec et al.; Olech; Sysa et al.; Wojcik \& Zima.

\section{MORPHOLOGY}

Bujak et al.: Cebulska: Dziurazik; Frąckowiak (1986 - 1, 2); Goscisḱa \& Glińska (1986 - 1, 2, 3); Gościcka \& Spoz (1986); Grottel et al. (1986); Janeczko; Klevezal \& Pucek; Knasiecka (1986); Kobryńczuk \& Krasińska; Lasota-Moskalewska et al.; Eakomy et al.; Maciejewski et al.; Markowskd \& Sikorski; Milart \& Hereć; Milart et al.; Miśksowiak; Ruprecht - 2; Ruprecht \& Szwagrzak; Sławomirski \& Gluczak (1986); Srebro; Strzalka et al.; Szteyn et al.; Zabel et al.; Zimny et al. (1986); Zioło \& Kubik (1986).

\section{PHYSIOLOGY}

Brelińska et al. (1986); Gębczyńska et al.; Gonet \& Kozłowski; Jakubow \& Gromadzka-Ostrowska - 1, 2; Koteja - 1; Niedźwiadek et al. - 2: Okarma \& Koteja; Piątkowska \& Wei- ner; Sawicka-Kapusta et al.; Stanisławska et al.; Szubartowska \& Gromysz-Kałkowska; Szymeczko; Weiner - 1, 2; Weiner \& Heldmaier; Witkowska \& Kotik; Zamojski et al.

1 Year of publication is given after the author's name only for papers published in 1986. It is omitted where it is 1987. 
4. REPRODUCTION, SEX, HYBRIDISATION

Cebulska; Jędrzejewska; Klevezal

Pucek; Kownacki et al (1986);
Rachowiak; Smielowski - 2; Weiner -1 .

\section{DEVELOPMENT}

Gościcka (\&\& Glinska (1988 - 1, 3); Janeczko; Klevezal \& Pucek; Kownacki \& Zuk (1986 - 1, 2); Kownacki et al. (1986); Michalak; Niedźwiadek et al. - 1; Sawicka-Kapusta, Czerwon-

ka \& Zakrzcwska; Szymeczko; Lavel et al.

\section{ECOLOGY, BIOLOGY AND CONSERVANCY}

Aulak \& Goszezyhskl; Banach 1; Caboń-Raczyńska et al. Dzięciolowski (1986); Gąsienica-Byrcyn; Gębczyński et al.; Gonet \& Kozlowskd; Groszceyński \& Pilatowski; liraczyk (1986); Harmata; Jakubiec \& Buchalczyk; Jędrzejewska; Kaleta \& Lewandowska; Kasperczyk; Kownacki \& Zuk (1986 - 1, 2); Kozaklewiez A. 1; Kozakiewicz M. et al; Kozakiewicz
M. \& Szacki; Kozlowsk1 \& Wojelk; Krasińska et al.; Krasiński - 1; Markowski \& Sikorski; Mazurkiewicz \& Rajska-Jurgiel; Okarma \& Koteja; Piątkowska \& Weiner; Sawicka-Kapusta; Sawicka-Kapusta, Górecki \& Lange; Sawicka-Kapusta, Czerwonka \& Zakrzewska; Sawicka-Kaplusta et al.; Szacki - 1; Smielowski - 1; Weiner $-2$.

\section{DISTRIBUTION, FAUNA AND SYSTEMATICS, PALAEONTOLOGY}

Bocheński et al.; Bogdanowicz \& Ruprecht; Cholewa; Cyrek \& Marosik (1986); Czyżewska; Dziurdzik; Gabryś \& Haitlinger (1986) Głowaciński \& Profus; Godula (1986); Graczyk et al. (1986); Haitlinger (1986 - 1,2, 3); Haitlinger $-1,2,3,4,5,6$; Jablońskd et al.; Jakubiec \& Buchalczyk; Kałuża; Kasperczyk; Kielan-Jaworowska et al.; Kielan-Jaworowska \& Trofimow (1986); Kowalski - 2; Kukurewicz; Lasota-Moskalewska et al.; Nowosad \& Sałata-Piłacińska; Parusel; Romankow-Żmudowska; Ruprecht - 1, 2; Rzebik-Kowalska; Szymański; Wolk 1, 2; Woloszyn; Zalewska-Schönthaler \& Szpakiewicz; Ziomek; Zurowski \& Kammler.

\section{PARASITES, EPIDEMIOLOGY AND PATHOLOGY}

Bluszez et al,; Demlaszkiewicz - 1, 2. 3; Dróżdż et al.: Gabryś \& Haitlinger (1986); Haitlinger (1986 - 1, 2, 3); Hai-

Accepted 20 September 1988.

Polish Academy of Sciences, Mammals Research Institute, 17-230 Bialowieża, Poland tlinger $-1,2,3,4,5,6$; Kingston et al.; Szymanski; Zalewska-Schonthaler \& Szpakiewicz; Zioło \& Kubik (1986). 